\title{
ТИХООКЕАНСКИЙ ФЛОТ КАК ФАКТОР БЕЗОПАСНОСТИ РОССИИ В КОНЦЕ ХІХ - НАЧАЛЕ ХХ ВЕКОВ
}

Становление в современных политических, социально-экономических и географических условиях новой геополитической системы обращает нас к опыту прошлого, когда в условиях военно-политических конфликтов конца XIX - начала XX века шло становление новой геополитической карты мира. Русско-японская война 1904-1905 гг. стала одним из первых образцов войны за геополитический передел мира, борьбой за «сферы влияния». Авторами проведено исследование правительственной политики национальной безопасности в контексте рассмотрения специфики различных взглядов русских главнокомандующих на формирование и техническое оснащение Тихоокеанского флота, что позволит представить более полную картину развития международных отношений и внешней политики того периода.

Научная новизна статьи определяется методологическими подходами и источниковой базой исследования. Материалы статьи являются результатом многолетних исследований развития отечественного кораблестроения в конце XIX - начала XX веков. Авторами представлен анализ внешней политики Российской империи в контексте исследования «Большой Азиат- ской программы». Уточнены причины поражения в русско-японской войне 1904-1905 гг. Рассматривается развитие военно-морских сил России на Дальнем Востоке с учетом новых фактов, раскрывающих специфику тактико-технологических свойств русских кораблей. Исследована роль И. А. Шестакова, Ф.В.Дубасова в занятии порта Мозампо, как альтернативного стратегического центра в военно-политическом противостоянии России и Японии на Дальнем Востоке. Выделяются дополнительные факторы, подтверждающие отставание темпов строительства и оснащения отечественных боевых броненосных кораблей на Дальнем Востоке. Дается анализ судостроительной программы России в связи с усилением ее присутствия на Тихом океане. Представлены новые данные о технологиях развития отечественного кораблестроения, о деятельности Обуховского сталелитейного, Балтийского и Адмиралтейского ижорского заводов в период подготовки к русской-японской войне.

Ключевые слова: «Большая Азиатская программа», геополитическая безопасность, Порт-Артур, Мозампо, И. А. Шестаков, Ф. В. Дубасов, русско-японская война, Тихоокеанская эскадра, кораблестроение.

\section{THE PACIFIC FLEET AS A FACTOR IN THE SECURITY OF RUSSIA AT THE END} OF THE XIX AND THE BEGINNING OF THE XX CENTURIES

The formation of a new geopolitical system in modern political, socio-economic and geographical conditions draws us to the experience of the past, when in the conditions of military-political conflicts of the late $X I X$ - early $X X$ century the formation of a new geopolitical map of the world took place. The Russian-Japanese war of 1904-1905 was one of the first examples of the war for geopolitical redistribution of the world, the struggle for "spheres of influence". The authors conducted a study of national security policy in the context of considering different views of the Russian commanders on the formation and technical equipment of the Pacific fleet. The study provides a more complete picture of the development of international relations and foreign policy of the period.

Methodological approaches and the source base of the research determine the scientific novelty of the article. The materials of the article are the result of many years of research into the development of Russian shipbuilding in the late $X I X$ - early $X X$ centuries. The authors present the analysis of the foreign policy of the Russian Empire in the con- text of the study of the "Great Asian program". The reasons for the defeat in the 1904-1905 Russian-Japanese war are clarified. The development of naval forces of Russia in the Far East is studied. The consideration of new facts reveals the peculiarities of tactical and technological properties of Russian ships. The role of I. A. Shestakova and F. V. Dubasov in the occupation of Mozampo port as an alternative strategic center in the military-political confrontation between Russia and Japan in the Far East is investigated. There are additional factors that confirm the lag in the pace of construction and equipping of national combat armored ships in the Far East. The analysis of the shipbuilding program of Russia in connection with the strengthening of its presence in the Pacific Ocean is given. New data on technologies of domestic shipbuilding development, on activity of Obukhov steel, Baltic and Admiralty Izhorskiye Factories during preparation for the Russian-Japanese war are presented.

Key words: Big Asian Program, geopolitical security, Port-Arthur, Mosampo, I.A. Shestakov, F.V. Dubasov, Russian-Japanese war, Pacific squadron, shipbuilding. 
В настоящее время Тихоокеанский регион стал ареной нового геополитического противостояния. Территориальные претензии Японии к России заставляют вспомнить события более чем столетней давности, когда противостояние великих держав вылилось в Русско-японскую войну 19041905 годов.

Экономическое развитие Российской империи в конце XIX века требовало активного освоения Сибири и Дальнего Востока. Правительство Николая II приступило к реализации «Большой Азиатской программы) целью, которой стало освоение дальневосточных территорий и активная внешняя политика в регионе. Япония в 1894 году начала с Китаем войну с целью установления контроля над Кореей. Китайская армия была изгнана японцами с Корейского полуострова, и начала бои непосредственно на китайской территории

Дпя обеспечения безопасного развития русского Дальнего Востока требовалось усиления военного присутствия России в этом регионе, развитие материально-технической базы фолота, прежде всего, создание броненосного фрлота и замена кадрового состава военно-морских сил. С этой целью, в 1880-е гг. управляющий Морским министерством вице-адмирал И. А. Шестаков посетил Владивосток и по результатам своих наблюдений составил доклад для Российского императора, в котором обосновывал необходимость нейтрализовать огромную опасность, которую представляет собой Япония для геополитических интересов Российской империи. Мощный боевой броненосный флот рассматривался им в качестве приоритетной задачи. В ответ на предложение Морского министра численность военно-морских сил на Тихом океане была увеличена [8, c. 31]. В упомянутом докладе Ивана Алексеевича Шестакова, согласно воспоминаниям А.Г Нидермиллера, была выражена следующая позиция: «Владивостокский порт, большой и удобный для стоянки кораблей большой эскадры, но не имеет открытого выхода в Тихий океан и в течение трёх-четырёх месяцев заперт льдами. Высказывалось пожелание о том, что России необходимо иметь на Тихом океане более южный порт. В связи с изложенными обстоятельствами, офицеры Тихоокеанской эскадры обследовали регион и остановили свой выбор на гавани Мозампо в южной части Кореи и бухте Киао-Чао (Циндао) на Шандунском полуострове. Последний порт в бухте Циндао был закреплён по соглашению с китайским правительством в качестве зимней стоянки для русских судов» $[5$, с. $459 ; 8$, с. 32$]$.

В 1895 году Россия, заручившись поддержкой Германии и Франции вмешалась в японо-китайскую борьбу и вынудила Японию отказаться от части своих завоеваний в Китае. Контр-адмирал Д. В. Никитин (Фокагитов), участник обороны Порт-Артура в своих воспоминаниях пишет: «чтобы без ненужной шумихи и огласки в тот период времени правящее российское правительство сосредоточило на Дальнем Востоке морские силы, превышающие японские. Японии был предъяв- лен ультиматум. Затаив злобу, японцы подчинились и ушли из Маньчжурии» $[9$, с. 46-47].

Однако, переговоры с китайским правительством по поводу аренды Порт-Артура длились долго. Следует отметить сохранившуюся актуальность порта Мозампо в качестве ресурсной базы Тихоокеанской эскадры. Так, ещё до окончания переговоров, адмирал Федор Васильевич Дубасов, впоследствии ставший командующим тихоокеанской эскадрой, прислал свой план относительно занятия порта Мозампо, который ранее уже фригурировал в плане И. А. Шестакова [6, с. 34]. Ф.В.Дубасов в 1897 гг. в декабре вошел в Порт-Артур. Как пишет С. Ю. Витте, получить Порт-Артур в аренду после занятия немцами Циндао, было трудно, да и порт Мозампо, который рекомендовал адмирал Ф. В. Дубасов, так же было не получить, вопрос аренды Порт-Артура удалось решить только, прибегнув к крупной взятке, о чём упоминал впоследствии отставной министр финансов С. Ю. Витте [2, с. 200].

Очевидно, что освоение Порт-Артура и порта Дальнего, как и Китайско-Восточной железной дороги (КВЖД), сыграло большую роль для развития геополитических и социально-экономических интересов России. В связи с тем, что КВЖД проходила по территории Маньчжурии, такие города, как Иркутск, Владивосток, Порт-Артур, Дальний удалось соединить в общую систему транспортной развязки, в качестве южной ветки Транссибирской магистрали. Она перенаправила основной грузопоток из Европы в Азию с морских перевозок, на железнодорожные, что сократило сроки доставки грузов в несколько раз и к началу XX века социально-экономическим результатом строительства дорога стало ускорение процесса заселения территорий Приамурья и Приморья, общий экономический подъем российского Дальнего Востока и Северной Маньчжурии. Таким образом, можно предположить, что занятие Российской империей Порт-Артура и порта Дальнего, строительство железной дороги, проходящей через Маньчжурию, не было захватом новых территорий, с последующим насильственным её освоением в одностороннем порядке, но сопровождалось оформлением соответствующих договоров. При этом заключенные между Россией и Китаем договоры, носили взаимовыгодный характер и были искренне одобрены государством и его представителями. При том, что «Большая азиатская программа», прежде всего, предусматривающая строительство транспортного коридора в Азиатско-Тихоокеанском регионе, имела первостепенное значение для царствования Николая II. Что касается отношения западных держав к российской дальневосточной политике, то усиление Российской Империи тревожило её соперника - Германию. Среди многочисленных воспоминаний современников событий, красочным представляется упоминание С. С. Ольденбургом [10, с. 55] переписки Вильгельма II и фон Бюлова: «если Англия и Япония будут действовать вместе, то они могут сокрушить Россию... Но им сле- 
дует поторопиться, иначе русские станут сильными» $[5$, с. 461].

Таким образом, главной задачей англо-саксонского мира, во главе которого стояла тогда «владычица морей» Великобритания, было не допустить усиления России в Азиатско-Тихоокеанском регионе, а эта задача, в свою очередь, предусматривала уничтожение русского флота Уничтожить русский фолот должна была Япония, которая, готовясь исполнить данную миссию, реализовала с помощью всесторонней материально-технической, военной и финансовой поддержки Великобритании, Германии и США три кораблестроительные кампании, создав первоклассный современный флот, предназначенный для осуществления своих и англо-саксонских геополитических планов. Как нами ранее отмечалось: «В конце 1903 года японский парламент высказался за войну с Россией. Однако японский император воспользовался правом «veto» и распустил парламент. Вновь избранный парламент снова проголосовал за войну с Россией, выразив агрессивные устремления японцев» [5, с. 460]

На Тихом океане с 1868 года [5, с. 461] находился небольшой отряд боевых кораблей, состоящий из семи железных судов разного типа и водоизмещения, оснащённых артиллерией: «Тунгус», “Ермак», “Бобр», «Сивуч», «Маньчжур», «Кореец", «Гиляк», и ежегодно обновляемый судами Балтийского фллота, базирующийся на Николаевске-на-Амуре. В 1870 году военно-морская тихоокеанская база была переведена во Владивосток. Эти суда имели стоянки в Японии между командами русских кораблей и местным населением завязались дружеские отношения $[8$, с. 15,21$]$. В конце 1896 года Военно-морской учёный отдел Главного Морского Штаба представил доклад, в котором поэтапно мотивировалась необходимость безотлагательного увеличения русских военно-морских сил на Дальнем Востоке В соответствии с этой неотложной задачей, вносилось предложение о проведении мероприятий по оборудованию и укреплению порта Владивосток в течение пяти лет, до конца 1901 года [8, с. 23]. В этом докладе подчёркивалось, что Япония, в силу объективных обстоятельств, способна закончить военные приготовления через семь лет т.е. к концу 1903 года. Кроме того, в этом докладе указывалась практически точная дата начала войны - конец 1904 года, когда будет закончено строительство железной дороги. Военно-морские учёные считали, что весь срок до предположительной даты войны должен быть использован для переброски войск и военного снаряжения по Байкалу: летом с помощью имеющихся двух паровых паромов, а зимой - по льду на подводах в Азиатско-Тихоокеанский регион [8, с. 23-24]. В докладе также специально отмечалось, что для нужд Тихоокеанского флота требуется осуществить заказ на строительство новых кораблей на иностранных верфях. При этом корабли должны поступить на вооружение Тихоокеанской эскадры за два года до даты предположительного начала войны с целью: сдерживания агрессивных устремлений Японии; для того, чтобы личный состав эскадры мог практиковаться в перспективе возможной войны [8, с. 24].

Главный Морской штаб запросил на создание Тихоокеанской эскадры 200 миллионов рублей, 90 из которых было отпущено тотчас в счёт уплаты заказов на строительство судов, а остальные 110 миллионов министр финансов С. Ю. Витте намеривался перечислить в течение семи лет в качестве ежегодной прибавки к сметам [3, с. 14].

Третий российский Императорский Тихоокеанский флот, как считает В. Ю. Грибовский, Николай II стремился создать по аналогии с Черноморским, взяв за основу Тавриду XVIII века. С этой целью российский император институирует структуру наместничества на Дальнем Востоке. Персональный состав руководства войсками Квантунской области и Морскими силами Тихого океана выглядел следующим образом: главный начальник и командующий - вице-адмирал Е. И. Алексеев с августа 1899 года, начальник морского отдела штаба - контр-адмирал В. К. Витгефт с января 1900 года [3, с. 10].

В 1897 году был определён оптимальный состав российского Императорского Тихоокеанского флота. Вот как описывает период создания Тихоокеанской эскадры В. Ю. Грибовский: «18 марта 1898 г. вице-адмирал Ф. В. Дубасов привёл в Порт-Артур броненосцы «Наварин» и «Сисой Великий», предназначенные выступить противовесом японским «Фудзи» и «Ясима». Ещё до 1900 г. на Дальнем Востоке были сосредоточены три эскадренных броненосца серии «Полтава», которые периодически совершали переходы из Владивостока и Порт-Артур с заходом в китайские и японские порты. «Наварин» и «Сисой Великий» были практически равноценными по боевой мощи кораблями, схожими в конструктивно-тактическом отношении. Оба корабля поступили на вооружение в середине 90-х гг., причём «Сисой Великий» проектировался по аналогии с «Наварином»» [11, с. 79]. «Корабли были вооружены четырымя 12 дюймовыми орудиями, расположенными на двух концевых башнях и шестью - восьмью 6-дюймовыми пушками, сосредоточенными в каземате, в середине корпуса; артиллерийское вооружение "Сисоя Великого" было более современным. При водоизмещении в 10200-10400 т и скорости хода около 15 узлов броненосцы отличались надёжным бронированием ватерлинии (406 мм - у «Наварина» брони марки компаунд, а у “Сисоя Великого» никелевой стали) и подводной палубы в 76 мм, обеспечивающей плавучесть при пробитии мягких оконечностей кораблей. В 1902 г. «Наварин» и «Сисой Великий» вернулись в Россию для ремонта, а затем ушли на Дальний Восток в составе группы судов под командованием контр-адмирала Д. Г Фелькерзама, участвовали в Цусимском сражении и затонули 15 мая 1905 г.» [3. с. 17].

В тот период отечественное кораблестроение ввиду небывалого роста объёмов заказов переживало бурное развитие. Лидером отечественного кораблестроения был Балтийский судостро- 
ительный и механический завод, на котором, среди прочих было построено пять эскадренных броненосцев из одиннадцати. На строительство одного броненосца уходило 39-40 месяцев, что вполне отвечало существующим мировым стандартам. Качество судостроительных работ на Балтийском заводе, по мнению В. Ю. Грибовского, было довольно высоким, поскольку на предприятии трудились выдающиеся кораблестроители своего времени: инженеры В. Х. Оффенберг, К. Я. Аверин, Н. Н. Кутейников [3 с. 6]. Остальные кораблестроительные предприятия в Российской Империи в ту пору не могли похвастаться столь высокой организацией производства, как Балтийский завод: так, броненосец «Ослябя» строился на Новом Адмиралтействе в течение 93 месяцев, в результате не успел в срок на театр военных действий $[6$, с. 163].

До начала XX века всю оптику для морской артиллерии Российская Империя заказывала за границей. Перед русско-японской войной отечественные оптические прицелы стал выпускать Обуховский сталелитейный завод, производственные мощности которого позволяли вооружить в год лишь два броненосца, исключая корабли других классов $[1$, с. 274]. Как отмечают военные исследователи Г. А. Антонов и В. А. ЦЦуварев, работы по созданию отечественных оптических прицелов для морской артиллерии велись на Обуховском сталелитейном заводе под руководством Я. Н. Перепёлкина. Обуховский завод выпустил знаменитое прицельное устройство «оптический прицел Обуховского завода образца 1903 года» с зависимой линией прицеливания и установкой прицела и целика, принятое на вооружение флота в 1904 году. Испытания прицела не были закончены к началу русско-японской войны, и заводу было поручено: срочно изготовить 300 прицелов для 2-ой Тихоокеанской эскадры.

Прицелы, изобретенные будущим советским академиком А. Н. Крыловым, в то время знаменитым математиком флота генерал-майором, устанавливались на кораблях эскадры прямо во время похода [1, с. 274]. Использование прицелов в боевых действиях обнаружило недостатки устройства. Так, в частности об этом изобретении А. Н. Крылова писал один из авторов сборника «С эскадрой Рождественского», выпущенного к 25-летию Цусимского сражения назвавшийся инициалами В. Б., однокашник адмирала Н. И. Небогатова. По словам В.Б., оптический прицел состоял из светящейся мушки, которая надевалась на дуло пушки, а также тонкой длинной трубки-стержня, идущей вдоль дула к казённой части орудия параллельно его оси и заканчивающейся трубою для глаза наблюдателя-комендора, который наводил орудие на цель. Но поскольку дуло пушки было длинным, трубка-стержень была тоже длинной, но, будучи тонкой, прогибалась, нарушая прямую линию. Во избежание прогиба, посередине трубки-стержня была вмонтирована крестовина, которая соединялась нитями с мушкой и трубой наблюдателя. Прекрасное в теории изобретение, но не прошедшее должного испы- тания, выходило из строя при каждом выстреле пушки, поскольку выстрелом прицел разрывало на части, нити лопались, а выведенный из себя комендор, исторгая ругательства, срывал прицел и стрелял на глаз [12, с. 125].

Большая часть материала для обшивки броненосных судов и различные судовые приспособления изготовлялись на Адмиралтейских Ижорских заводах. В 1898 году на этих заводах производилась броня, закалённая по методу Круппа. Метод Круппа считался в то время самой современной технологией. Однако, ввиду низкой производительности, российские заводы хронически не поспевали обслуживать растущие потребности отечественного кораблестроения, поэтому Российское правительство вынуждено было прибегнуть к иностранным заказам [11, с. 114]. В 1899 году капитан 1-го ранга И. К. Григорович был назначен командиром строившегося во Франции, в Тулоне эскадренного броненосца «Цесаревич». Испытания корабля начались только в 1903 году и проходили непросто: во время испытаний выяснились конструктивные недостатки подачи 305 мм снарядов и главных машин. За процессом испытаний наблюдал прибывший из Петербурга помощник начальника ГМШ контр-адмирал А. А. Вирениус. Но ему не пришлось вести на Дальний Восток отряд новых кораблей: задержал повреждённый в Гибралтаре броненосец «Ослябя». Вёл «Цесаревич» в Порт-Артур И. К. Григорович. Во Франции был построен крейсер 1-го ранга «Баян», которым впоследствии командовал капитан 1-го ранга Р. Н. Вирен.

Ввиду того, что в то время всесильный министр финансов С.Ю. Витте держал военно-морской фрлот на строгой финансовой диете, выбор типов судов при строительстве определялся не их тактико-техническими качествами, а дешевизной производства. Так, обсуждая весьма скромные тактико-технические возможности сошедших в преддверии войны со стапелей верфей Санкт-Петербургского порта однотипных крейсеров, носящих имена древнегреческих богинь: “Диана», «Паллада» и “Аврора», можно отметить, что эти суда, обладающие внушительным водоизмещением 6630 т., были оснащены слабой артиллерией, причём орудия были установлены без броневой защиты, и даже с целью защиты не предусматривалось щитов. На судовых испытаниях полные обводы корпусов крейсеров не дали кораблям возможности развить заданную скорость в 20 узлов. Выполнение крейсерских задач также оставалось под вопросом, поскольку весьма незначительная скорость не позволяла этим судам выполнять с надёжностью разведку; в бою они не были в состоянии обеспечить поддержку броненосцам ввиду слабости артиллерии и защиты; а относительно небольшая дальность плавания - 4000 миль затрудняла их использование на протяжённых переходах [6, с. 121]. По личному указанию Николая II со стапелей Балтийского завода сошёл очередной и последний в этой серии океанских судов - крейсер «Громобой», строившийся в течение трёх лет с 1897 по 1900 гг. по 
усовершенствованному проекту [3, с. 11]. Однако «Громобой» имел частичное поясное бронирование. Но самым главным недостатком последнего океанского крейсера было то, что установленные в количестве двадцати четырёх штук 75 мм пушки в реальности не способствовали увеличению мощности артиллерии корабля [11, с. 187].

Таким образом, как отмечено в воспоминаниях В. П. Костенко, соотношение сил Японии - России было неравномерным. «К концу 1903 года на вооружении российской оперативной военно-морской базы, размещенной в Порт-Артуре, в составе 1-ой Тихоокеанской эскадры, и вспомогательного Владивостокского крейсерского отряда в целом насчитывалось семь броненосцев, четыре броненосных, семь бронепалубных и лёгких крейсеров. У Японии к началу войны было 6 броненосцев, 8 броненосных крейсеров, 12 легких крейсеров 8 канонерских лодок, 27 эскадренных миноносцев и 19 миноносцев. Следовательно, на стороне японского флота было почти двойное превосходство в легких силах. Кроме того, силы русской эскадры были разъединены между двумя базами, удаленными одна от другой на 1060 миль» [7]. Современный исследователь А. В. Шишов выразил мнение о сосредоточении главных сил в составе 7 броненосцев и 7 крейсеров в Порт-Артуре [14 c. 123]. Между тем, согласимся с Костенко В. П. что: «В Порт-Артуре еще не был закончен док для ввода броненосцев, тогда как во Владивостоке имелся достаточной величины” [7]. Однако, отсутствие дока для броненосцев в Порт-Артуре как нами ранее отмечалось [5, с.461], вопреки за- явлению исследователя А. В. Шишова, «не имело в дальнейшем самых тяжелых последствий благодаря таланту военного инженера, капитана Зборовского, предложившего в отсутствии сухого дока, производить ремонт повреждённых броненосцев «Цесаревич» и «Ретвизан» при помощи присасывающих кессонов» [14, с. 123-124].

Нехватка финансовых, технических и административно-организационных ресурсов сказались на процессе завершения строительства кораблестроительной базы и сборке подводных лодок и миноносцев на Дальнем Востоке и Владивостоке. Только лишь в 1902-1903 гг. в Порт-Артуре была построена небольшая верфь для сборки миноносцев, строившихся в Санкт-Петербурге и доставлявшихся в разобранном виде по железной дороге $[3$, с. 6,12 ; 14 , с. 124]. Во время русскояпонской войны в Порт-Артур прибыла бригада кораблестроителей с Балтийского завода, о работе которой с благодарностью вспоминали артурцы.

Неготовность к войне осознавалась и в правительственных кругах. Так, ещё в ноябре 1895 г. Николай II оставил знаменитую заметку: «Вся наша беда именно состоит в том, что России приходится строить и содержать три самостоятельных флота» [3, с. 15]. К сожалению многие мероприятия по усилению Тихоокеанского флота не были завершены. Это предопределило поражение России в войне с Японией. Поражение в войне и последующие революционные потрясения привели к тому, что Россия только спустя десятилетия снова смогла начать активное освоение тихоокеанских берегов.

\section{Источники и литература}

1. Антонов Г. Н., Цуварев В. А. Труды военно-морских исторических конференций. СПб: Санкт-Петербургское Морское Собрание. Дом учёных российской академии наук, 2006. 628 с.

2. Витте С. Ю. Воспоминания: Царствование Николая II. - изд. 2-ое. Т.2. Л.: Гос. изд., 1924. 518 с.

3. Грибовский В. Ю. Российский флот Тихого океана 1898 - 1905: История создания и гибели. М.: Изд-во ООО Военная книга, 2004. 45 с.

4. Дацышен В. Г. Русско-китайская война. Манчжурия 1900 год. СПб: Издательство: ООО «Галея Принт», 1996. 144 c.

5. Зубов А. Ю. Информационно-психологическая агрессия, направленная против русского флота в годы русско-японской войны 1904 - 1905 гг. // Известия Санкт-Петербургского государственного аграрного университета. 2015. №39. C. $456-462$.

6. Капитанец И. М. Флот в русско-японской войне и современность. М.: Вече, 2004. 163 с.

7. Костенко В. П. На «Орле» в Цусиме. Воспоминания участника русско-японской войны на море в 1904-1905 гг. Л.: Судпромгиз. 1955. 544 c. URL: https://statehistory.ru/books/V--P--Kostenko_Na-Orle-v-TSusime--Vospominaniyauchastnika-russko-yaponskoy-voyny-na-more-v-1904-1905-gg-/3. (Дата обращения: 06.06.2019).

8. Нидермиллер фон А. Г. От Севастополя до Цусимы: воспоминания: русский флот за время с 1866 по 1906 г. Рига: издание М. Дидковского, 1930. 144 с.

9. Никитин (Фокагитов) Д. В. Как началась война. Порт-Артур. Воспоминания участников. Нью-Йорк: Изд.-во им. А. П. Чехова, $1955.412 \mathrm{c}$.

10. Ольденбург С. С. Царствование Императора Николая II [Репр. воспр. изд. Вашингтон, 1981]. СПб: Петрополь, $1991.644 \mathrm{C}$.

11. Павлов Д. Б. На пути к Цусиме: беспримерный поход 2-й Тихоокеанской эскадры. М.: Вече, 2011. 114 с.

12. Сборник статей, посвящённых двадцатипятилетию похода II эскадры Тихого океана. Прага: издательство В. Колесникова, $1930.126 \mathrm{c.}$

13. Тычин И. К. Труды военно-морских исторических конференций. СПб: Санкт-Петербургское морское собрание. Дом ученых российской академии наук, 2006. 628 с.

14. Шишов А. В. Россия и Япония: История военных конфликтов. М.: Вече, 2000.574 с. 


\section{References}

1. Antonov G. N., Czuvarev V. A. Trudy 'voenno-morskix istoricheskix konferencij. Sankt-Peterburgskoe Morskoe Sobranie Doma Uchyony'x (Works of Military and Maritime Historical Conferences). St. Petersburg: Maritime Assembly of the House of Scientists St. Petersburg, 2006. 628 p. (In Russian).

2.Vitte S. Yu. Vospominaniya: Czarstvovanie Nikolaya II. Vol. 2. (Memoirs: The Reign of Nicholas II). Leningrad: State Publishing House, 1924. 518 p. (In Russian).

3. Gribovskij V. Yu. Rossijskij flot Tixogo okeana 1898-1905: Istoriya sozdaniya i gibeli. (Russian Pacific Fleet 1898-1905: History of Creation and Death). Moscow: Publishing House LLC Military Book, 2004. 45 p. (In Russian).

4. Dacyshen V. G. Russko-kitajskaya vojna. Manchzhuriya 1900 god (Russian-Chinese war. Manchuria 1900). St. Petersburg: Publisher: LLC «Halley Print», 1996. 144 p. (In Russian).

5. Zubov A. Yu. Informacionno-psihologicheskaya agressiya, napravlennaya protiv russkogo flota v gody russko-yaponskoj vojny 1904-1905 gg. (Information and Psychological Aggression Aimed at the Russian Navy during the Russian-Japanese war of 1904-1905) // Izvestiya of St. Petersburg state agrarian University. 2015. No.39. P. 456-462. (In Russian).

6.Kapitanecz I. M. Flot v russko-yaponskoj vojne i sovremennost'. (Fleet in the Russian-Japanese War and Present Time). Moscow: Veche, 2004. 163 p. (In Russian).

7. Kostenko V. P. Na "Orle» v Cusime. (On the "Orel" in Tsushima). Leningrad: Sudpromgiz., 1955. 544 p. URL:https:// statehistory.ru/books/V--P--Kostenko_Na-Orle-v-TSusime-Vospominaniya-uchastnika-russko-yaponskoy-voyny-na-more-v1904-1905-gg-/3 (Accessed: 06.06.2019). (In Russian).

8. Nidermiller fon A. G. Ot Sevastopolya do Czusimy: vospominaniya: russkij flot za vremya s 1866 po $1906 \mathrm{~g}$. (From Sevastopol to Tsushima: Memories: the Russian Fleet from 1866 to 1906.). Riga: edition of M. Didkovsky, 1930. 144 p. (In Russian).

9. Nikitin (Fokagitov), D. V. Kak nachalas' vojna. Port-Artur. Vospominaniya uchastnikov. (How the War Began. Port-Arthur. Memories of the Participants.) / D.V. Nikitin (Fokagitov). New York, 1955. 412 p. (In Russian).

10. Ol'denburg S. S. Czarstvovanie Imperatora Nikolaya II (The reign of Emperor Nicholas II). St. Petersburg: Petropol, 1991. 644 p. (In Russian).

11. Pavlov D. B. Na puti k Czusime: besprimerny`j poxozh 2-j Tixookeanskoj e’skadry`. (On the way to Tsushima: unalterable campaign of the 2 nd Pacific Squadron). Moscow: Veche, 2011. 114 p. (In Russian).

12. Plavanie otryada admirala Nebogatova. S e skadroj Rozhdestvenskogo. (Swimming detachment of Admiral Nebogatov. With the squadron of Rozhdestvensky) // Sbornik statej, posvyashhyonny 'x dvadczatipyatiletiyu poxoda II e'skadry' Tixogo okeana. Prague: V. Kolesnikov publishing house, 1930. 126 p. (In Russian).

13. Ty 'chin I. K. Uroki Czusimy`. Vzglyad iz sovremennosti. (K stoletiyu Czusimskogo srazheniya). Doklad. 26-27 maya 2005 g. (Lessons of Tsushima. A Look from the Present. (To the Centenary of the Tsushima Battle). Report. May 26-27, 2005). St. Petersburg: Sankt-Peterburgskoe morskoe sobranie. Dom uchenyh rossijskoj akademii nauk, SPb.: St. Petersburg Maritime meeting. House of scientists of the Russian Academy of Sciences, 2006. 433 p. (In Russian).

14. Shishov A. V. Rossiya i Yaponiya: Istoriya voenny’x konfliktov. (Russia and Japan: A History of Military Conflicts). Moscow: Veche, 2000. 574 p. (In Russian)

\section{Сведения об авторах}

Зубов Алексей Юрьевич - старший преподаватель кафедры истории и управления персоналом Санкт-Петербургского государственного университета гражданской авиации (Санкт-Петербург) / aleksey.zubow2013@yandex.ru

Сидненко Татьяна Ивановна - доктор исторических наук, профессор кафедры государственного и муниципального управления, директор центра образовательных технологий Ленинградского государственного университета им. А. С. Пушкина (Санкт-Петербург)/ sidnenko@list.ru

\section{Information about the authors}

Zubov Aleksej - senior teacher, Chair of History and Staff Management, St. Petersburg State University of Civil Air-Craft (St. Petersburg) / aleksey.zubow2013@yandex.ru

Sidnenko Tatiana - Doctor of History, Professor, Chair of State and Municipal Management, Head of Center for Educational Technology, Pushkin Leningrad State University (St. Petersburg) / sidnenko@list.ru 